\title{
PROBLEMS ASSOCIATED WITH THE UTILIZATION OF INFORMATION AND COMMUNICATION TECHNOLOGIES AMONG FARMERS IN SOUTHEAST AGRO ECOLOGICAL ZONE OF NIGERIA
}

\author{
*OKWUSI, M. C. \\ *National Root Crops Research Institute, Umudike, \\ P.M.B. 7006, Umuahia, Abia State, Nigeria
}

\begin{abstract}
The study examines problems associated with the utilization of information and communication technologies (ICTs) in Southeast agro ecological zone of Nigeria. Data for the study was collected with the aid of interview schedule from 270 randomly selected farmers in the study area. Data analysis was thorugh the use of mean scores. The identified problems associated with the utilization of ICTs include ignorance, lack of ICT resources, cost of access is high, not capable in manipulating some ict facilities, lack of electricity supply, lack of network coverage, cyber problem. It is therefore recommended that adequate structure be put in place to remove these problems so that usage of information and communication technologies will be adequate.
\end{abstract}

Key words: problems, information and communication technologies, farmers

\section{INTRODUCTION}

Experience over the past decade according to World Bank (2006), has shown that a vibrant and competitive information and communication sector is a prerequisite for developing information societies. Lessons can be drawn that may be particularly valuable for countries launching new policies and programs to increase ICTs contribution to economic and social development and extend its reach to a greater part of the population. Additional and complementary efforts are also needed to ensure the success of such programs, particularly increased monitoring and evaluation, based on appropriate goals, targets, and indicators. When tailored to needs, ICT has the potential to raise growth in businesses of any size and countries at any stage of development. Related, but even more important, is ICTs role in reducing poverty and inequality, both within and across countries. Thus, it is crucial that ICT move closer to the mainstream of development economics and policies nationally, regionally, and globally. Given ICTs far-reaching payoffs and the many efforts required to achieve them this report is aimed not only at ICT experts but also at the broader development community.

ICTs play a vital role in advancing economic growth and reducing poverty. Research in the 1960s and 1970s showed how telecommunications strengthen economic production and distribution, public service delivery, and government administration. In the 1980s information became recognized as a crucial factor of production, along with capital and labour. And in the 1990s globalization and the increasing information intensity of economic activity, coupled with rapid technological change and demand growth, made ICT critical to competitiveness and growth. When used well, ICT can also make management and operations more efficient. The internet can be especially valuable for firms in developing countries because it provides opportunities to connect to markets and participate in trade, domestic and foreign. A recent survey of 56 developed and developing countries found a significant link between Internet access and trade growth, with the greatest benefits accruing to developing countries with the weakest trade links (World Bank, 2006). As with other factors of production, such as capital and labour, ICT use differs, based on business size, ownership, and export orientation. In developing countries, Web site and computer (though not necessarily e-mail) use are more common among service firms than firms engaged in 
manufacturing, agro industry, and construction. Web site and e-mail use are especially high in the telecommunications, information technology, real estate, hotel and restaurant industries, among exporters and foreign-owned firms. Among regions, firms in Central and Eastern Europe use such technology the most, reflecting its correlation with national income. But Web sites and e-mail are also widely used in some low-income countries such as Bangladesh, Kenya, Moldova, and Tanzania suggesting that ICT is not a luxury. ICT is also crucial to sustainable poverty reduction, because it makes a country's economy more efficient and globally competitive, improves health and education services, and creates new sources of income and employment for poor people. In addition, ICT enhances social inclusion and promotes more effective, accountable, democratic government, especially when combined with effective freedom of information and expression (ITU, 2003).

Over the past 25 years, developing countries have considerably increased ICT access, especially for telephone services. Developing countries accounted for more than 60 percent of the world's telephone lines (fixed and mobile) in 2005, up from less than 20 percent in 1980. During this period, population increased by half and real GDP more than doubled in these countries while the number of telephone subscribers rose 28-fold (ITU, 2003).

Recent growth has been especially striking. Although the proportion of subscribers to total population in developing countries did not even double between 1980 and 1990, over the next decade it nearly quintupled, from 27 to 129 per 1,000 people. And between 2000 and the end of 2005, it is estimated to have tripled, reaching almost 400 subscribers per 1,000 people (World Bank, 2005). Most of the recent growth has involved mobile phones, which now outnumber fixed ones. In Nigeria the number of mobile subscribers jumped from 370,000 in 2001 to 16.8 million in September 2005, making its mobile market the second largest in Africa. In the Philippines, which had more mobile than fixed telephone subscribers since 2000, mobile subscribers continue to multiply. By the end of 2005, the country had about 40 million mobile subscribers - six times more than in 2000 (World Bank, 2006).

Mobile phones have an especially dramatic impact in developing countries substituting for scarce fixed connections, increasing mobility, reducing transaction costs, broadening trade networks, and facilitating searches for employment. With prepaid services and calling cards, even poor households have been able to benefit from increased telephone access (World Bank, 2005). Telephone services now reach many small cities and towns, and by 2005 half of the world's households had telephones. Among developing regions the telephone subscription rate is highest in Europe and Central Asia, where between 2000 and 2004 it more than doubled to 730 per 1,000 people. But growth was highest in Sub-Saharan Africa, with the rate tripling albeit to a still-low 103 subscribers per 1,000 people (World Bank, 2005).

Other types of ICT have also expanded rapidly in recent years. The latest estimates indicate that worldwide, internet use more than quadrupled between 2000 and 2005. Again, Europe and Central Asia is in the lead among developing regions, with 117 internet users per 1,000 people in 2004 four times as many as in 2000 and six to eight times as many as in South Asia and Sub-Saharan Africa. During this period the fastest growth, 370 percent, occurred in the Middle East and North Africa. Liberalization and competition and the resulting increase in private investment have driven the development of telecommunications infrastructure and ICT in general. Capital is crucial to the development and expansion of robust telecommunications networks. Because developing countries often lack the capital as well as the technology and managerial know-how needed to develop such networks, many have turned to private investors, domestic and foreign. By opening their telecommunications markets through well designed reforms, governments can create competitive markets that grow faster, lower costs, facilitate innovation, and respond better to user needs. As a result, the traditional monopoly model of telecommunications services based on extensive state 
control and protected national markets has eroded, in concert with rapid technological advances in the sector and fundamental changes in economic policy in developing countries.

The internet has also spurred a growing wave of innovation, ushering in new services and more cost-effective network solutions especially in countries where service providers are allowed to build their own networks and gateways. New wireless technology is resulting in innovative business models and holds the promise of connecting poor users, extending competition to all market segments, and accelerating development of broadband infrastructure and access. Such technology is affordably priced and commercially viable in a number of countries, in both urban and rural areas. For example, a single broadband internet connection in a village can provide access for numerous institutional programs (such as egovernment and computers in schools) and private users (World Bank, 2006).

ICT also reduces the historical advantages of long established firms. This allows firms from developing countries greater opportunities to participate in international trade and become connected to foreign markets. Clarke and Wallsten (2004), in a study of 27 highincome countries and 66 developing countries, found that a 1 percentage point increase in the number of internet users boosts total exports by 4.3 percentage points, and increases exports from low-income countries to high-income countries by 3.8 percentage points. Freund and Weinhold (2004), in a study that included 56 developed and developing countries, also found a significant link between access to the internet and trade growth for the period 1997-9. Specifically, they found that developing countries with the fewest established trade links benefit the most from using the internet.

Furthermore, the internalization of ICT applications affects business operations directly. The ability to transfer information seamlessly through shared electronic files and networked computers improves the efficiency of business processes such as documentation, data processing, and other back-office functions (for example, organizing incoming orders and preparing invoices). Increasingly sophisticated ICT applications such as customer resource management (CRM) and electronic data interchange (EDI) allow firms to store, share, and use their acquired knowledge. All this can reduce inefficiencies in the use of capital and labor and can lower operational and transaction costs among economic agents, thus improving the productivity and profitability of firms. The use of ICT in rural Nigeria is beset with myriads of problems. As a result this study investigates problems associated with the utilization of ICTs.

\section{METHODOLOGY}

The study was carried out in the southeast agro ecological zone of Nigeria. There are nine states within the South East agricultural zone, namely, Abia, Akwa-Ibom, Anambra, Cross River, Enugu, Imo, Rivers, Bayelsa, and Ebonyi states. The respondents involved in the study were randomly selected from three states in the study area since all the states are fully engaged in agricultural production. The states included Anambra, Abia and Akwa Ibom States respectively. Three agricultural zones were randomly selected from the states apart from Abia State with only three zones. The selected zones were Aba, Umuahia and Ohafia in Abia state; Ikot Ekpene, Uyo and Eket in Akwa Ibom state and Awka, Onitsha and Anambra in Anambra state. From the three agricultural zones, one block was randomly selected. Also, from each block one circle was randomly selected and thereafter, 30 farmers each were also selected randomly from a list of farmers complied by the ADP staff. This implies that 90 farmers were interviewed in each state giving a total of 270 farmers from the three states. A total of 270 respondents were drawn from 9 circles of the three states. Nine ADPs staff were recruited and thoroughly trained in the administration of well designed interview schedule; working under researcher's supervision. One set of structured interview schedule was developed and used for data collection. Descriptive statistics was employed in data analysis. 


\section{RESULTS AND DISCUSSION \\ Problems associated with the utilization of ICTs in the Study Area}

Table 1 depicts identified problems associated with the utilization of ICTs among farmers. Findings showed that ignorance with mean value of 2.42 was identified as a serious problem. In the rural area, some of the farmers claimed that they have no knowledge of ICTs (internet, CD-ROM and fax) as it is used for agricultural information exchange.

Table 1: Problems Associated with the Utilization of ICTs

\begin{tabular}{|c|c|c|c|c|c|}
\hline Problems & Very serious & Moderately & Less serious & Mean & Remarks \\
\hline & & serious & & & \\
\hline Ignorance & $121(44.8)$ & $\begin{array}{l}140 \\
(51.9)\end{array}$ & $\begin{array}{l}9 \\
(3.3)\end{array}$ & 2.42 & Serious \\
\hline Lack of ICT resources & $\begin{array}{l}140 \\
(51.9)\end{array}$ & $\begin{array}{l}122 \\
(45.2)\end{array}$ & $\begin{array}{l}8 \\
(3.0)\end{array}$ & 2.48 & Serious \\
\hline Cost of access is high & $\begin{array}{l}191 \\
(70.7)\end{array}$ & $\begin{array}{l}67 \\
(24.8)\end{array}$ & $(4.4)$ & 2.66 & Serious \\
\hline $\begin{array}{l}\text { Type of information in the net } \\
\text { is not useful }\end{array}$ & $\begin{array}{l}7 \\
(2.6)\end{array}$ & $\begin{array}{l}70 \\
(25.9)\end{array}$ & $193(71.5)$ & 1.31 & Less serious \\
\hline Government policy on ICTs & $\begin{array}{l}19 \\
(7.0)\end{array}$ & $\begin{array}{l}68 \\
(25.2)\end{array}$ & $183(67.8)$ & 1.39 & Less serious \\
\hline $\begin{array}{l}\text { Not capable in manipulating } \\
\text { some ICT facilities }\end{array}$ & $151(55.9)$ & $\begin{array}{l}102 \\
(37.8)\end{array}$ & $\begin{array}{l}17 \\
(6.3)\end{array}$ & 2.49 & Serious \\
\hline Lack of electricity supply & $168(62.2)$ & $\begin{array}{l}85 \\
(31.5)\end{array}$ & $17(6.3)$ & 2.56 & Serious \\
\hline $\begin{array}{l}\text { Lack of spare parts of ICTs } \\
\text { resources }\end{array}$ & $21(7.8)$ & $\begin{array}{l}101 \\
(37.4)\end{array}$ & $148(54.8)$ & 1.53 & Less serious \\
\hline Lack of network coverage & $231(85.6)$ & $\begin{array}{l}17 \\
(6.3)\end{array}$ & $22(8.1)$ & 2.77 & Serious \\
\hline Cyber problem & $68(25.2)$ & $\begin{array}{l}187 \\
(69.3) \\
\end{array}$ & $15(5.6)$ & 2.19 & Serious \\
\hline
\end{tabular}

Source: Computed from Survey Data 2007.

Mid point $=2.00$; any mean $<2.0$ is less serious. Any mean $\geq 2.0$ is serious .

Table 1 also revealed that lack of ICT resources was also identified as a serious problem with the mean value of 2.48. This was mostly observed in the rural areas where radio, television and G.S.M. was mastly available unlike internet, CD-ROM, fax, e.t.c. High cost of access with the mean value of 2.66 was another identified serious problem associated with the utilization of ICTs. The high cost could be attributed to the fact that some of the cyber cafes operators use their personal generators to run their business, especially in the use of internet networking which is a new medium of communication and requires electrical power for its use. This agrees with Arokoyo (2005), who noted high cost of ICT as major constraint in agricultural extension in developing countries. In the same vein, not being able to manipulate some ICTs (intenet, CD-ROM, fax, e.t.c.), was also identified as a serious problem with the mean value of 2.49. This was as a result of lack of training as observed among farmers. Moreso, the literacy level of some of the farmers in the study area contributed to their incapability in the use of some of these ICTs.

Findings of the study revealed that lack of electric power supply was yet another major problem with the mean value of 2.56. As observed in some areas visited, there was no electricity and in some areas, epileptic. This is in conformation with Daily Independence Friday, October 5, 2007, which stated that today, many people cannot utilize the whole range of these ICTs equipment because of the high cost of power, lamenting that ICTs training in particular is suffering on account of the lack of power supply. Lack of network coverage and 
cyber problem with mean values of 2.77 and 2.19 respectively were identified as problems associated with he utilization of ICTs. This could be attributed to the sophisticated nature of the equipment and the technical know-how involved in the operation and citing of internet server.

The identified problems associated with the utilization of ICTs are seen as some of the reasons of digital divide. World Bank, (2006), lamented that the Gaps in access to ICT remain large, as do differences in adoption of ICT applications. Access to ICT is highly unequal across and within countries, particular, developing countries still have far to go to make ICT commonplace in governments, schools, and businesses. Moreover, fast growth in large emerging markets especially Brazil, China, and India masks slower development elsewhere. Although, progress has been made reaching out to rural areas and the urban poor, in many countries these groups still lag behind and the advanced information and communication services available through the internet initially reach mainly better-off groups. Adesope (2004) and Adesope, et al (2007) reported that problems affecting the use of Information Technology to include poor funding, inadequate budgetary allocation, lack of training, inadequate personal training and inadequate facilities for information technology

According to World Bank (2006), developing countries often face obstacles to adopting and using ICT applications, as a result of slow, unreliable, insufficient, and expensive telecommunications services; corruption, many firms have to pay bribes for service licenses or telephone connections; limited incentives to change business models and operating structures when the costs of adopting ICT are significant and returns uncertain. Many firms especially those that are small, domestically owned, or non-exporting do not recognize the value of ICT strategies or applications for their activities, and do not feel that they need ICT beyond a basic level of connectivity; lack of trust in online business activities and related legal impediments and shortages of workers skilled in ICT.

\section{CONCLUSION AND RECOMMENDATIONS}

Information and communication technology has helped to add value to agricultural information development in Nigeria. Despite this, several problems have been identified with the utilization of ICTs. The study found the problems to include ignorance, lack of ICT resources, cost of access is high, not capable in manipulating some ict facilities, lack of electricity supply, lack of network coverage, cyber problem. It is therefore recommended that adequate structure be put in place to remove these problems so that usage of information and communication technologies will be adequate.

\section{REFERENCES}

Adesope O.M., Asiabaka C.C and Matthews-Njoku, E. C. (2007). Problems affecting the use of information technologies as perceived by Extension Managers in Nigeria. In: A.C. Agumagu, et al., (eds) Contemporary issues in Agricultural Extension and development studies. Series one. Omoku: Molsyfem United Services

Adesope, O.M (2004). Information technology needs of agricultural extension managers and supervisors in the Niger Delta area of Nigeria. Unpublished PhD Thesis. Federal University of Technology, Owerri.

Arokoyo, T. (2005). ICTs Application in Agricultural Extension Service Delivery. In: Adedoyin S. F. (ed) Agricultural Extension in Nigeria. Ilorinf: Agricultural and Rural Management Training Institute, pp 245-251. 
Journal of Agriculture and Social Research (JASR) VOL. 10, No. 2, 2010

Clarke, George, and Scott Wallsten. (2004). "Has the Internet Increased Trade? Evidence from Industrial and Developing Countries." World Bank Policy Research Working Paper 3215, World Bank, Washington, DC.

Freund, Caroline L., and Weinhold, Diana (2004). "The Effect of the Internet on International Trade." Journal of International Economics 62 (1): 171-89.

International Telecommunication Union (2003). World Telecommunication Development Report. Geneva: ITU.

World Bank (2005) World Development Indicators database.

World Bank (2006) Information and Communications for Development; Global 